\title{
Front-End Governance of a Major Public Project in Laos: A Conceptual Framework for Ensuring the Right Concept
}

\author{
Nikhaphone Mackhaphonh *, Guangshe Jia and Qixiong Xu \\ Department of Construction Management and Real Estate, School of Economics and Management, Tongji University, Shanghai,
} China

Major public projects in Laos are faced with multiple challenges, including project identification and its decision-making. Generally, an identification is an important key identifying the potential needs and requirements for achieving the development goal. However, the process was developed without a formal framework and assurance tools that have been criticized for negative social and environmental consequences as "white

OPEN ACCESS

Edited by:

Zhen Chen,

University of Strathclyde,

United Kingdom

Reviewed by:

Alex Opoku,

University College London,

United Kingdom

Manu Sasidharan,

University of Cambridge,

United Kingdom

*Correspondence:

Nikhaphone Mackhaphonh

nikhaphon@163.com

Specialty section:

This article was submitted to Construction Management,

a section of the journal

Frontiers in Built Environment

Received: 21 November 2020

Accepted: 02 June 2021

Published: 24 August 2021

Citation:

Mackhaphonh N, Jia G and Xu Q (2021) Front-End Governance of a

Major Public Project in Laos: A Conceptual Framework for Ensuring the Right Concept.

Front. Built Environ. 7:631919

doi: 10.3389/fbuil.2021.631919 elephant projects" over the past few years. Considering this context, the study aimed to develop a conceptual framework to navigate an alternative solution for the right project. Based on contextual analysis and systematic literature review, the proposed framework provided the process of concept development and its assurance that it could be systematically developed in a cause-effect chain of needs. The findings indicate areas that reflect new insights of both strategic performance and a governance system, and reforms the decision-making process in providing new knowledge, new rules, and procedures for effective governance.

Keywords: front-end governance, concept assurance, governance framework, public projects, Laos

\section{INTRODUCTION}

Major infrastructure projects in Laos are considered at the national level as major public projects, with relevance to many central and local organizations, and provide high benefit or impact for driving the country's development (Public Investment Law, 2015). Over the past few years, many public investment projects have been criticized for negative social and environmental consequences due to delivery of infrastructure public projects dubbed "white elephant projects". These projects have been modified or even stopped during the implementation, even projects that had implemented rules and regulations. A recent publication examined the key challenges of governing major infrastructure projects in Laos (Mackhaphonh et al., 2019), the most important challenges occurred during "project identification," as important processes were lacking identification, the identification was developed without a formal framework and insufficient attention was paid to problems during the front-end governance. Subsequently, the publications emphasized concept assurance to help solve a problem or satisfy a need in improving strategic performance as an alternative solution for the right project (Hobbs and Aubry, 2008; Klakegg et al., 2008; Garland, 2009; Müller, 2009; Morris and Geraldi, 2011; Andersen, 2012; O’Leary, 2012; Shiferaw and Klakegg, 2012; Samset and Volden, 2016b). The process is essential to identify potential 


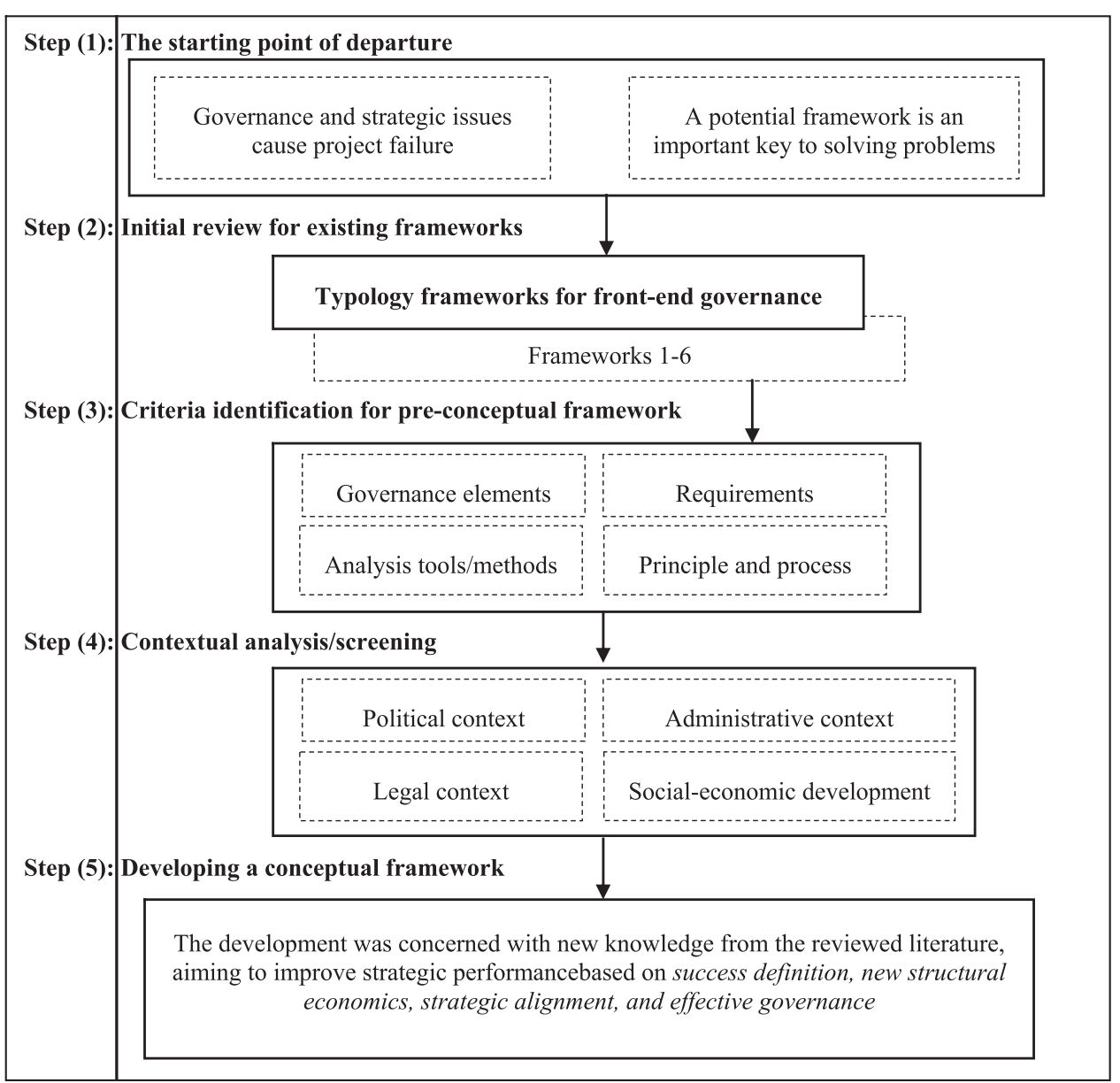

FIGURE 1 | Research framework.

needs, requirements, and goals during strategic development, and concept assurance is emphasized to ensure that public projects can achieve strategic goals. Accordingly, the study aimed to develop a conceptual framework on how the right concept could be identified and ensured in a cause-effect chain of needs. By doing this, the research considers the principle of effective governance in defining the rules and procedures for making decisions, then defining the development framework and monitoring system. The findings proposed the important process of pursuing the right project and implicating the policy maker as well as reforming the decision-making process and priority consideration on strategic requirements, control functions, and alignment.

\section{RESEARCH FRAMEWORK}

Qualitative research was conducted based on contextual analysis and a systematic literature review to map the existing literature with categorizes of data including presenting the existing issues and ideas of project concept assurance (Grant and Booth, 2009). The review concerns the decisions regarding the development system, the context, requirements, and the characteristics for ensuring the right project is undertaken. The research framework was designed with a comprehensive procedure including elements of a systematic process consisting of five steps (Figure 1).

Step (1): The point of departure states the front-end development context, that research findings identified the issues of front-end governance and strategic issues of major infrastructure projects which had been investigated as the important challenges that occurred in the project identification in terms of lack of a decision-making framework on the concept phase and the issue of strategic alignment. The procedure was conducted as a thematic analysis (Figure 2) that built on investigating the governance context, getting familiar with the data through transcription of front-end governance in using a pattern matching technique with the initial tentative patterns represented.

Step (2): An initial review for the existing frameworks from six OECD countries (Table 1), including Norway, the Netherlands, the United Kingdom, Sweden, Denmark, and Canada (Quebec). The review 


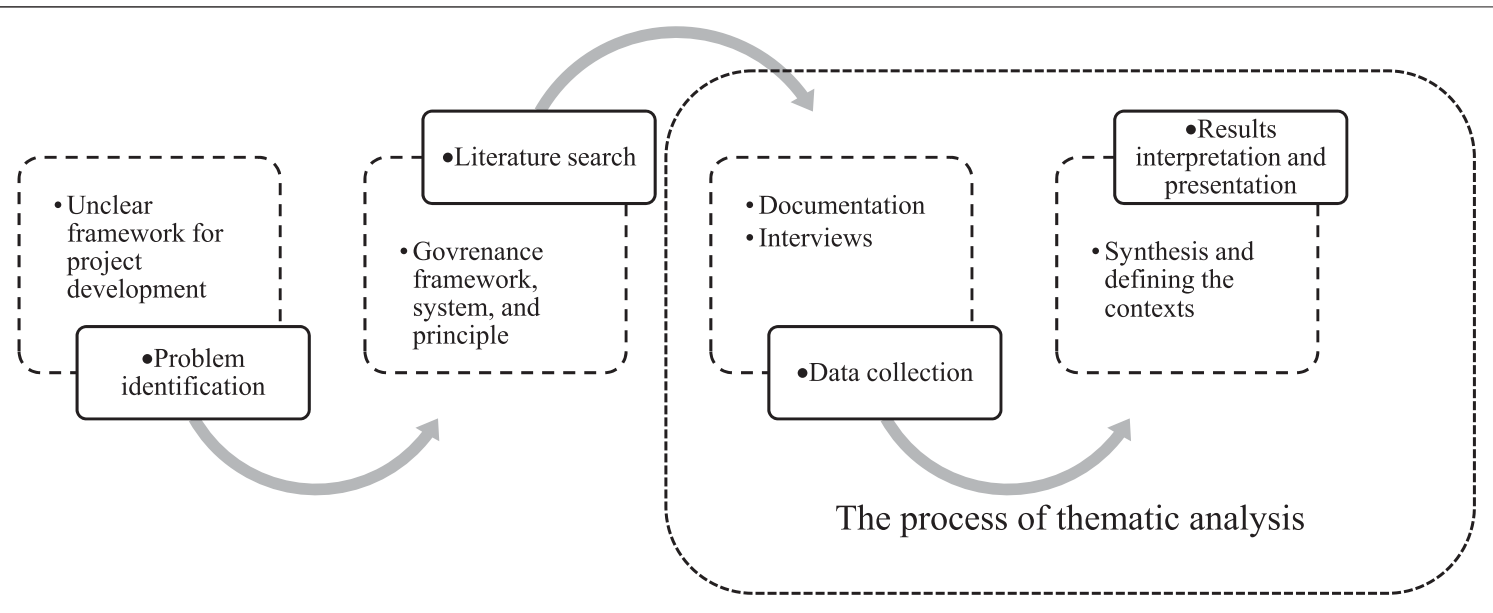

FIGURE 2 | The research framework for governance context.

TABLE 1 | The front-end assurance tools of major public projects in six OECD countries.

\begin{tabular}{|c|c|c|}
\hline $\begin{array}{l}\text { Six OECD } \\
\text { Countries }\end{array}$ & $\begin{array}{l}\text { Concept } \\
\text { assurance/decision framework }\end{array}$ & Aims \\
\hline Norway & Quality assurance 1 (QA1) & Ensure strategic success, with evaluating effects and societal objectives \\
\hline United Kingdom & OGC gateway process (gateways 0,1 , and 2) & $\begin{array}{l}\text { Considering the need of stakeholders around the projects on how to best ensure that projects are } \\
\text { successful }\end{array}$ \\
\hline Denmark & Decision level 1 (only to road and rail projects) & Provides a basis for a decision to examine certain specific alternatives and political decisions further \\
\hline Sweden & $\begin{array}{l}\text { Strategic choice of measures (for the transport } \\
\text { sector) }\end{array}$ & $\begin{array}{l}\text { Highlighted through the application of problems and needs relating to the functioning of which } \\
\text { stakeholders will be affected }\end{array}$ \\
\hline Netherlands & MIRT process (MIRT1) & $\begin{array}{l}\text { A concern with society's needs and priorities with general strategies provides the region with } \\
\text { opportunities and interest to come to an agreement, such as effect amongst affected parties }\end{array}$ \\
\hline Canada (Quebec) & SQI and SCT (stage 1 and stage 2) & $\begin{array}{l}\text { Project-relevant conceptual solutions are available for selection, clarifying alternatives and funding } \\
\text { schemes }\end{array}$ \\
\hline
\end{tabular}

divided the key features of the concept decision into three characteristics: elements, criteria, and function. It is necessary as guidelines and tools to select, analyze, and prioritize the project concept.

Step (3): Identifying the pre-conceptual framework divides it into elements, requirements, functions, and principles of decision-making, which is important to provide the big picture to see the context and system of the potential framework. The identifying process is based on thematic analysis (Braun and Clarke, 2006); which investigates the governance elements. The research involved an in-depth understanding of documents and interview data, which were summarized and named in codes; coding describes the texts and shorthand as keywords describes an article. Each code will have a description. In the second step, the codes allow us to analyze data and compare similarities, differences, and relationships among segments. Finally, the initial codes were generated based on the transcripts, then combined into preliminary themes, which were shared into essential themes for the final summary finding.
Finally, the findings are discussed and compared to different perspectives, e.g., OECD contexts.

Step (4): Analysis and screening based on contextual analysis to be carried out to identify the features and criteria from the political, administrative, legal, and socialeconomic development contexts. The synthesis technique was conducted concisely summarizing and linking different sources in order to review the literature on a topic, make recommendations, and connect the data to the research.

Step (5): The idea of a conceptual framework emphasized improving strategic performance, which can solve both governance and strategic issues. Besides, the literature studied provided the perspective, knowledge, requirements, and solving concept that other researchers conducted for the different contexts examined in the same area. Therefore, the construct of the conceptual framework is the most important process that is considered from the governance system, and the decision-making structure, requirements, and controlling system function during the early phase of project 
development. Besides, the literature studied an idea for improving strategic performance such as success definition, accounting for development aspects, aligning strategies, and allowing effective governance, which were important strategies for governance improvement.

\section{WHAT CONSTITUTES THE "RIGHT CONCEPT?"}

\section{The Success Definition}

Project success was emphasized by researchers in many perspectives (Baccarini and Collins, 2004; Bayiley and Teklu, 2016; Bowen et al., 2007; Cooke-Davies, 2002; Diallo and Thuillier, 2005; Ika, 2009; Joslin and Müller, 2016; Shenhar et al., 2001). It is defined as doing the right project, meeting objectives of stakeholder satisfaction, satisfying needs, achieving particular targets, and attaining a beneficial project outcome, etc. (Baccarini and Collins, 2004; Ika, 2009; Joslin and Muller, 2016; Musawir et al., 2017). Success is also reflected in the views of "doing the right project," which provides little benefit to users and society. A study on project success has to define two levels, operational and strategic success (Samset and Volden, 2014), including the operational success targets related to time, cost, and quality during the project implementation. At the concept level, strategic success is affected, where the business case and stakeholder requirements play an essential role, involving the effects of the project's outcomes on users and society. Its concern with "relevance, sustainability, and effectiveness" was related to the social aspects of prioritized needs and other possible effects for ensuring strategic performance (Klakegg, 2006; Klakegg, 2009; Jonny Klakegg and Haavaldsen, 2011; Samset and Volden, 2016b).

\section{Strategic Alignment}

Strategic alignment emphasizes an important activity that needs business strategy (Crawford et al., 2008; Patanakul and Shenhar, 2012; Samset and Volden, 2012; Samset and Volden, 2016a). It can contribute to the realization of the concept and its consistency with the achievement of its goal, linking the project to strategic planning and, consequently, performance (Cooke-Davies, 2002; Morris and Geraldi, 2011; Samset, 2009; Williams and Samset, 2010). It describes the important side of the alignment between business strategy and portfolio, program, or project objectives (Turner and Muller, 2003). This link could allocate scarce resources to high-priority public needs and elicit public enterprises' desired behavior (Baum and Tolbert, 1986). It is possible to create a link between development strategy and project objectives and control whether project objectives are prepared based on the public's needs and priorities (Klakegg et al., 2008).

\section{"New Structural Economics"}

"New structural economics" has suggested a framework to complement previous approaches for sustainable growth strategies that facilitate both industrial upgrading and infrastructure improvements (Lin, 2011). It considered infrastructure improvement in developing countries as inclusive growth in the driving force for poverty reduction, including factor and

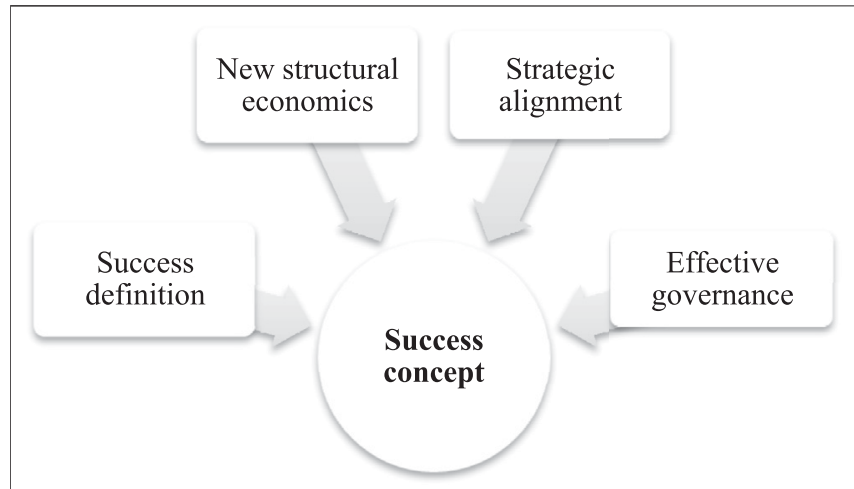

FIGURE 3 | Elements for improving project concept.

infrastructure endowments, level-wise development, and the corresponding industrial social-economic development structures. The idea of concept development under the framework of new structural economics should be considered from a strategic development standpoint, which is based on involving industrial upgrading and corresponding improvements of infrastructure at each level to add infrastructure as another component in "hard" infrastructure (tangible) and "soft" infrastructure (intangible) with the other social and economic arrangements to facilitate its operations and transactions.

\section{Effective Governance}

Governance effectiveness can be determined from "good governance" requirements (Graham et al., 2003; Ochieng et al., 2016; UNESCAP, 2009; Woods, 2000; World Bank, 1992) and various measurements have been used to evaluate effectiveness. These measurements include meeting technical performance, such as quality, functionality, or reliability, etc. (Hoegl and Gemuenden, 2001; Hoegl and Parboteeah, 2007; Lee, 2008; Webber, 2008), meeting customer and user requirements (Liang et al., 2007), meeting project goals related to quality, and meeting market focuses (Qiu et al., 2009; Van Der Vegt and Stuart Bunderson, 2005). The studies also mentioned that a governance framework could solve problems that arise with governance systems and other processes to select the right project, checking the alignment of project objectives with government policies and strategies, and allowing the involvement of relevant stakeholders in the project preparation and decision-making processes. The concept of effective governance delivers the selected project in a way that meets the expectations of the right concept and that institutional values and objectives can be considered in the selection and implementation of the project's success (Argyriades, 2006; Weaver and Services, 2007; Garland, 2009). Such governance depends on the processes, rules, and structures of the project governance system and how these elements support project selection, decision-making, and implementation based on four principles (Garland, 2009). Therefore, it is necessary to specify the distribution of rights and responsibilities among stakeholders, defining the rules and procedures for making decisions, defining the strategic framework, and monitoring performance to ensure transparency and accountability at all levels to facilitate the project's success. 


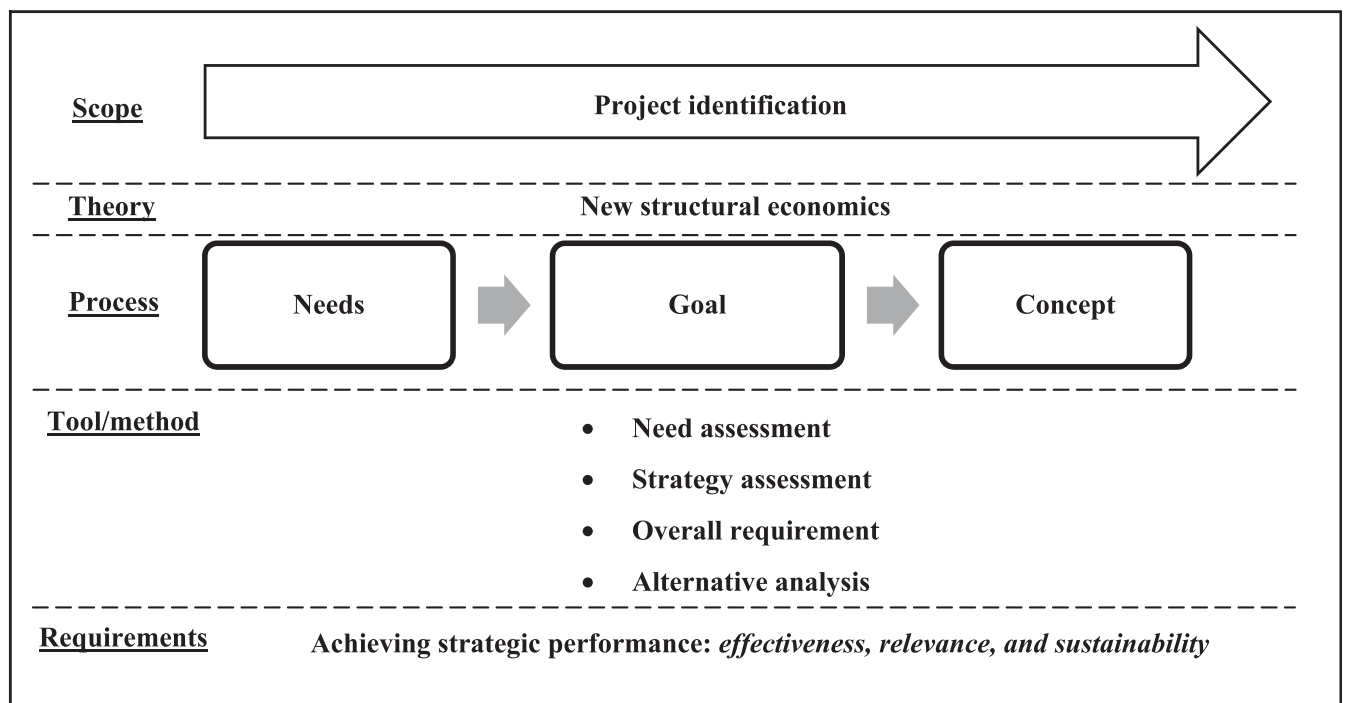

FIGURE 4 | Defining the elements of decision-making.

\section{IMPROVING THE SUCCESS CONCEPT}

The project concept is an important key to identifying potential needs, requirements, and goals during the frontend development phase, and concept assurance was emphasized to ensure that public projects could achieve their strategic success. Ensuring the right concept is based on having clear objectives and requirements and establishing appropriate control measures to ensure the project concept's quality. The literature review identified elements to ensure the right concept and the definition of success, accounting for development aspects, aligning strategies, and allowing effective governance, which are essential for overall achievement (see Figure 3).

\section{THE PROPOSED OF A CONCEPTUAL FRAMEWORK}

\section{The Elements of Decision-Making}

The conceptual framework provided critical elements and consistent methods of controlling the project development for decision-making, it proposed the scope, theoretical aspects, development process, screening tools, and requirements (shown in Figure 4).

\section{Decision-Making Process}

The literature provided assurance tools in the decision-making process to ensure the right concept from a strategic level, the key features of the concept decision was split into three characteristics, elements, criteria, and function for the decision of public investment projects (Klakegg, 2009; Samset, 2010; Jonny Klakegg and Haavaldsen, 2011; Shiferaw and Klakegg, 2012). Then, the key elements of the overall process can be summarized based on a review process that examines project concepts at the critical decision points and checks the successful progress of projects at the specified key checking points before allowing it to progress to the next step to ensure quality of the project concept (see Figure 5).

- Need assessment: Expressed indirectly through demands, affected parties, and assesses relevance with their needs and priorities, which contain the important aspects of several objectives, linked and parallel, which shall be derived from the needs. The analyses were divided into three main categories: normative, market-oriented, and interest group-oriented (Næss, 2009; Næss, 2011).

- Overall strategy: Specified based on consistent, realistic, and verifiable immediate and long-term objectives, it defines the project's goal and purpose, emphasizing consistency, realism, and verifiability. Based on contextual characteristics, the three main strategies involve inclusive growth, three-build (San Sang), and integrated.

- Overall requirements: These need to be fulfilled, for instance, functional, aesthetic, physical, operational, and economic requirements, in which the business and stakeholder requirements play an essential role in meeting the expected needs of users and businesses.

- Alternative analysis: Defines the zero-option and at least two alternative concepts, specifying their operational objectives and essential uncertainty based on the formulated problem, according to the objectives, values, criteria, and boundaries.

\section{Goal Setting}

The goal-setting formulated in this context often omits important and relevant societal needs and objectives governing the choice of the main concept solution for infrastructure development. As a basis for analysis, consistent consideration of these important structural components of governance, referred to within the 


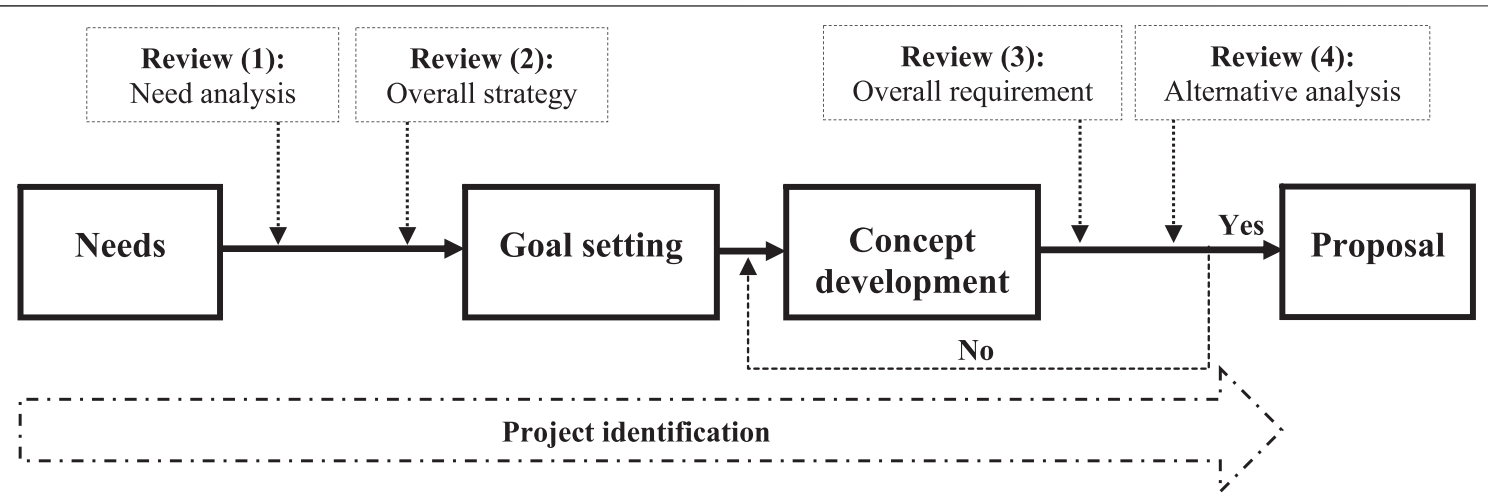

FIGURE 5 | Development process of the project concept.

\section{Define priority and criteria}

Theories of "new structural economics" define inclusive growth for sustainable development, based on facilitating both industrial upgrading and infrastructure improvements (Lin, 2011).

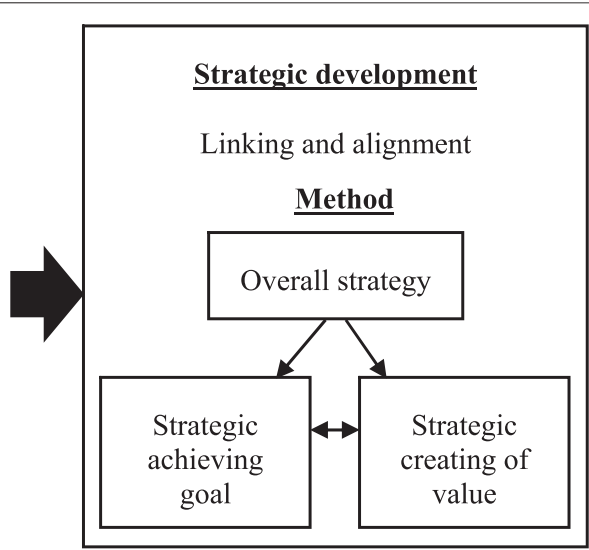

FIGURE 6 | The process of goal-setting.

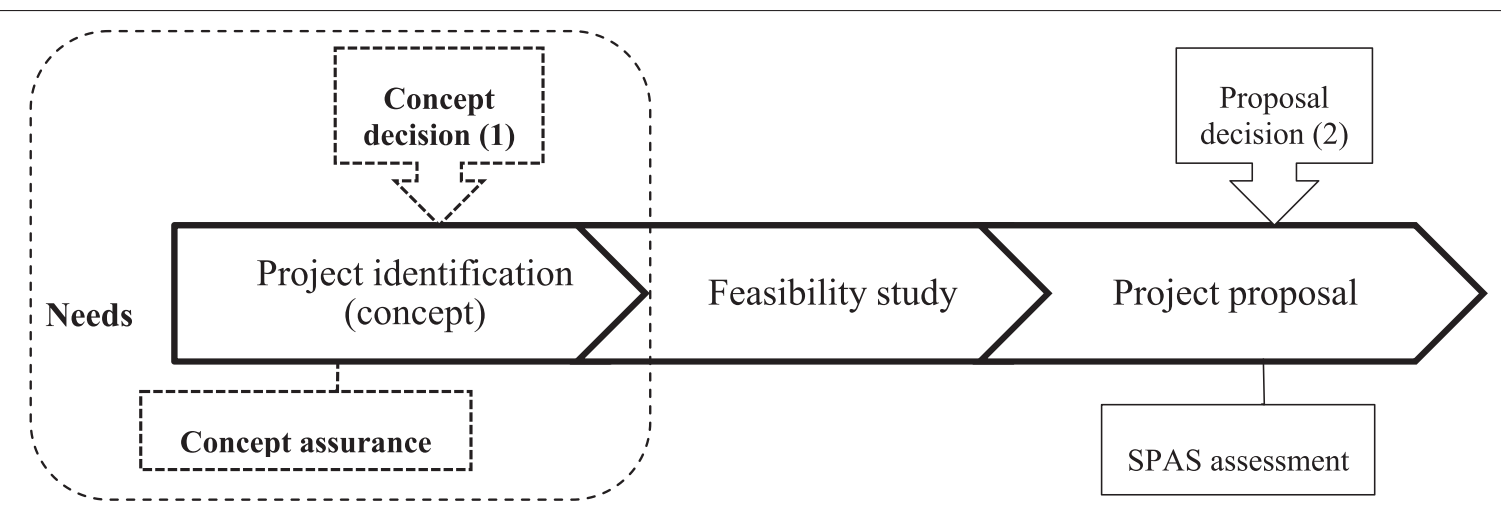

FIGURE 7 | Model of concept assurance.

standard policy, planning, or action learning cycles, determines the standard structural activity components of governance systems in setting higher-level visions/objectives and identifying the best strategies for securing visions and strategic objectives (see Figure 6).

\section{DISCUSSION}

How Can the Right Concept be Ensured?

The proposed framework involves processes and principles to ensure the project concept's quality (right concept), which did not 
exist in the Laos's context (see Figure 7). The alignment is considered an important process within a business strategy when setting the project development goal, linking the project to strategy between business strategy and portfolio, program, or project objectives (Turner and Muller, 2003). It focuses on existing problems to express an undesirable condition for a positive effect, the review processes check the critical decision points and improve the concept's quality, ensuring that the choice of project concept is rational for the strategic requirements. The framework emphasized that strategic issues arising due to the early development process are developed without a concept of helping or solving a problem and satisfying a need. The new framework provides a clear decision process, and supports efficient and effective project initiation to allow effective governance (Garland, 2009).

Ensuring the right concept starts with improving the quality of the concept which can be achieved through the rational choice of a project concept considering the problems, needs, and priorities, checking the project's objectives, strategies, and policies against overall requirements, and searching for alternative solutions. The overall process of concept development focuses on "system analysis" (Samset, 2010; Samset and Volden, 2012). Thus, need analysis is an important tool to include the project-relevant and politically prioritized needs of a proposed investment project. Whereas systems analysis provides a logically coherent chain of analysis where the problem is interpreted as a system or an opportunity space with requirements that must be fulfilled for the system to be functional and take into consideration the needs and objectives of key stakeholders. In addition, the social process with the economic and social aspects of the project, as opposed to the technical aspects, should meet the needs of many stakeholders within the project organization and the wider environment (Miller and Hobbs, 2005; Samset, 2010). When the needs or problems are identified, the choice of concept is chosen as the starting point of several alternative proposed solutions to the overriding problem, guided by the original problem and the expected effect. In this context, the idea of infrastructure development under new structural economics is essential to express an existing development context through the principle of inclusive growth to facilitate both industrial upgrading and infrastructure improvements (Lin, 2011). It maps all stakeholders and affected parties within relevant sectors of society as the point of departure, and all relevant societal needs to be considered (Shiferaw and Klakegg, 2012; Williams and Samset, 2010).

\section{What Improves Strategic Success?}

In pursuit of strategic success, the alignment of objectives is the basic logical structure outlining the project by following the causal link from the basic needs of users and society (Samset and Volden, 2016b). The proposed framework involves strategy development for decision-makers to anticipate, understand, and drive the development strategy to identify the goals and objectives for better project performance (Williams and Samset, 2010). The function of linking and alignment can reflect needs by including several objectives to help check and control the goals and objectives across commitments, the availability of alternatives, prioritization, and other factors to achieve the right public projects. It is possible to create a link between development strategy and the objectives of projects to control whether or not project objectives are prepared based on the public's needs and priorities (Klakegg et al., 2008). Alignment deals with this confusion and shows how the relationship between the parent organization and the project affects the development of a cause-and-effect chain. At this point, the goals are consistent in many areas that lead to the target, and potential needs may be expressed indirectly through the demands and needs of affected parties, and the relevance of their needs and priorities may be assessed to better align the project concept with development policies. Thus, strategic consideration, that is considered through defined goals to the delivery of project results, may successfully become a common feature of projects. In addition, the study indicated that areas for improvement in strategic performance include the three criteria of "relevance, sustainability, and effectiveness" as important requirements to ensure strategic success (Samset and Volden, 2016b).

- The research made efforts to improve effectiveness in developing contemporary processes to facilitate the function of achieving objectives and goals, supporting economic development towards the growth theory, and abandoning white elephant projects through concept assurance.

- Improving relevance through need and problem identification, aligning with the needs and priorities, and aligning with development strategy are essential so that the framework extent and objectives are aligned with the needs and priorities of users and the affected parties.

- The development of a conceptual framework has a defined structure and principles to improve sustainability considering the social, ecological, and economic values regarding express requirements, considering all relevant stakeholders' concerns, and increasing the investment value, which are utilized to increase the value of the investment when possible.

\section{CONCLUSION}

Pursuing a right public project is meaningful for major infrastructure improvements. However, the front-end governance in Laos lacks important processes, and projects have been developed without a formal framework to ensure the right concept during "project identification," which has resulted in "white elephant projects". Accordingly, this study developed a conceptual framework for concept development and its assurance in providing an alternative solution for front-end governance in Laos. Based on contextual analysis and systematic literature review, the development framework explained how initial activities could be conducted to systematically develop a cause-effect chain of needs and problems to identify alternative solutions, as a set of decision-making processes regarding the governance element. The study reformed the decision-making process and provided new knowledge, rules, and procedures to identify more effective solutions. Identification referred to the principle of "new structural economics", which is a priority 
theory, to clarify the most appropriate project strategy in the perspective of hard and soft infrastructure. It also provided the sets of the review process to check the critical decision points to improve the quality of the concept, ensuring the choice of the project concept is rational for requirements of strategic performance and the exact function to meet the following criteria in a clear objective, provide a clear governance structure, and support the efficient and effective project initiation in allowing effective governance. The study provided an in-depth solution to public investment projects at a strategic level, implementations for policy makers in ensuring right concept, and an infrastructure development principle for the context of a developing country. Thus, the limit of application is not reflected for enterprise projects and countries within a different context. Therefore, further research is needed to consider these frameworks in a wider context and to examine other types of infrastructure development to cater for public needs and priorities.

\section{REFERENCES}

Andersen, E. S. (2012). Illuminating the Role of the Project Owner. Int. J. Managing Projects Bus 5 (1), 67-85. doi:10.1108/17538371211192900

Argyriades, D. (2006). Good Governance, Professionalism, Ethics and Responsibility. Int. Rev. Administrative Sci. 72 (2), 155-170. doi:10.1177/ 0020852306064607

Baccarini, D., and Collins, A. (2004). "The Concept of Project Success - what 150 Australian Project Managers Think," in Proceedings of the 2004 Australian Institute of Project Management Conference, Perth 2004, 10-12th October, 2004 (Western Australia: AIPM 2004), 48-57. 10.1.1.534.101268

Baum, W. C., and Tolbert, S. M. (1986). Investing in Development: Lessons of World Bank Experience*. Development South. Africa 3, 199-218. doi:10.1080/ 03768358608439228

Bayiley, Y. T., and Teklu, G. K. (2016). Success Factors and Criteria in the Management of International Development Projects. Int. J. Managing Projects Business 9 (3), 562-582. doi:10.1108/IJMPB-06-2015-0046

Bowen, P. L., Cheung, M.-Y. D., and Rohde, F. H. (2007). Enhancing IT Governance Practices: A Model and Case Study of an Organization's Efforts. Int. J. Account. Inf. Syst. 8 (3), 191-221. doi:10.1016/ j.accinf.2007.07.002

Braun, V., and Clarke, V. (2006). Using Thematic Analysis in Psychology. Qual. Res. Psychol. 3, 77-101. doi:10.1191/1478088706qp063oa

Cooke-Davies, T. (2002). The "Real" success Factors on Projects. Int. J. Project Management 20 (3), 185-190. doi:10.1016/S0263-7863(01)00067-9

Crawford, L., Cooke-Davies, T., Hobbs, B., Labuschagne, L., Remington, K., and Chen, P. (2008). Governance and Support in the Sponsoring of Projects and Programs. Project Management J. 39 (S1), S43-S55. doi:10.1002/ pmj.20059

Diallo, A., and Thuillier, D. (2005). The success of International Development Projects, Trust and Communication: An African Perspective. Int. J. Project Management 23 (3), 237-252. doi:10.1016/j.ijproman.2004.10.002

Garland, R. (2009). Project Governance: A Practical Guide to Effective Project Decision Making. London, UK: Kogan Page.

Graham, J., Amos, B., and Plumptre, T. (2003). Principles for Good Governance in the 21st Century. Ottawa, Canada: Institute on Governance (IOG). august, 9. Policy Brief.

Grant, M. J., and Booth, A. (2009). A Typology of Reviews: an Analysis of 14 Review Types and Associated Methodologies. Health Info. Libr. J. 26 (2), 91-108. doi:10.1111/j.1471-1842.2009.00848.x

Hobbs, B., and Aubry, M. (2008). An Empirically Grounded Search for a Typology of Project Management Offices. Project Management J. 39, S69-S82. doi:10.1002/pmj.20061

\section{DATA AVAILABILITY STATEMENT}

The original contributions presented in the study are included in the article/supplementary material, further inquiries can be directed to the corresponding author.

\section{AUTHOR CONTRIBUTIONS}

All authors listed have made a substantial and intellectual contribution to the work, and approved it for publication.

\section{ACKNOWLEDGMENTS}

The authors would like to thank and show their appreciation for GJ and the research team for their inspirational support and guidance from the beginning to the end.

Hoegl, M., and Gemuenden, H. G. (2001). Teamwork Quality and the Success of Innovative Projects: A Theoretical Concept and Empirical Evidence. Organ. Sci. 12 (4), 435-449. doi:10.1287/orsc.12.4.435.10635

Hoegl, M., and Parboteeah, K. P. (2007). Creativity in Innovative Projects: How Teamwork Matters. J. Eng. Technology Management 24 (1-2), 148-166. doi:10.1016/j.jengtecman.2007.01.008

Ika, L. A. (2009). Project success as a Topic in Project Management Journals. Project Management J. 40 (4), 6-19. doi:10.1002/pmj.20137

Jonny Klakegg, O., and Haavaldsen, T. (2011). Governance of Major Public Investment Projects: in Pursuit of Relevance and Sustainability. Int. J. Managing Projects Bus 4 (1), 157-167. doi:10.1108/ 17538371111096953

Joslin, R., and Müller, R. (2016). The Relationship between Project Governance and Project success. Int. J. Project Management 34 (4), 613-626. doi:10.1016/ j.ijproman.2016.01.008

Klakegg, O. J. (2006). Formulation of Objectives in Major Public Investment Projects. Concept Report no. 6. Concept Program. Trondheim, Torgarden, Norway: Norwegian University of Science and Technology. Retrieved from http://www.concept.ntnu.no.

Klakegg, O. J. (2009). Pursuing Relevance and Sustainability: Improvement Strategies for Major Public Projects. Int. J. Managing Projects Business 2 (1), 499-518. doi:10.1108/17538370910991115

Klakegg, O. J., Williams, T., and Magnussen, O. M. (2008). Governance Frameworks for Public Project Development and Estimation. Project Management J. 7 (3), 47-67. doi:10.1002/pmj

Lee, L. T.-S. (2008). The Effects of Team Reflexivity and Innovativeness on New Product Development Performance. Ind. Management Data Syst. 108 (4), 548-569. doi:10.1108/0263557081086838010.1108/ 02635570810883978

Liang, T. P., Liu, C. C., Lin, T. M., and Lin, B. (2007). Effect of Team Diversity on Software Project Performance. Industr Mngmnt Data Syst. 107 (5), 636-653. doi:10.1108/02635570710750408

Lin, J. Y. (2011). New Structural Economics: A Framework for Rethinking Development. The World Bank Res. Observer 26, 193-221. doi:10.1093/ wbro/lkr007

Mackhaphonh, N., Jia, G., Mou, Q., and Zhang, P. (2019). Governing Major Infrastructure Projects in Laos: The Context of Front-End. Int. J. Business, Econ. Management Works 6 (03), 31-37. doi:10.5281/zenodo.2583045

Miller, R., and Hobbs, B. (2005). Governance Regimes for Large Complex Projects. Project Management Journal 36 (3), 42-50. doi:10.1177/875697280503600305

Morris, P. W. G., and Geraldi, J. (2011). Managing the Institutional Context for Projects. Project Management J. 42 (6), 20-32. doi:10.1002/pmj.20271

Müller, R. (2011). Project Governance. Transport 12. doi:10.1093/oxfordhb/ 9780199563142.003 .0013 
Musawir, A. u., Serra, C. E. M., Zwikael, O., and Ali, I. (2017). Project Governance, Benefit Management, and Project success: Towards a Framework for Supporting Organizational Strategy Implementation. Int. J. Project Management 35, 1658-1672. doi:10.1016/j.ijproman.2017.07.007

Næss, P. (2011). Needs Analysis. NTNU Concept-Program, Concept Re. NTNU (Trondheim, Torgarden, Norway). Retrieved from http://www.concept.ntnu.no.

Næss, P. (2009). "Up-front Assessment of Needs," in Making Essential Choices with Scant Information: Front-End Decision Making in Major Projects. United Kingdom: Palgrave Macmillan. doi:10.1057/9780230236837

Ochieng, R. M., Visseren-Hamakers, I. J., Arts, B., Brockhaus, M., and Herold, M. (2016). Institutional Effectiveness of REDD+ MRV: Countries Progress in Implementing Technical Guidelines and Good Governance Requirements. Environ. Sci. Pol. 61, 42-52. doi:10.1016/j.envsci.2016.03.018

O'Leary, T. (2012). "Decision-making in Organisations," in Project Governance: Getting Investments Right, 175-220. United Kingdom: Palgrave Macmillan. doi:10.1057/9781137274618

Patanakul, P., and Shenhar, A. J. (2012). What Project Strategy Really Is: The Fundamental Building Block in Strategic Project Management. Project Management J. 43, 4-20. doi:10.1002/pmj.20282

Public Investment Law (2015). Public Investment Law. Vientiane, Laos, 1-34. Retrieved from https://www.jica.go.jp/project/laos/015/materials/ku57pq00001ssrajatt/ MidtermRpt_1year_en.pdf.

Qiu, T., Qualls, W., Bohlmann, J., and Rupp, D. E. (2009). The Effect of Interactional Fairness on the Performance of Cross-Functional Product Development Teams: A Multilevel Mediated Model. J. Product. Innovation Management 26, 173-187. doi:10.1111/j.1540-5885.2009.00344.x

Samset, K. (2010). Early Project Appraisal. United Kingdom: Palgrave Macmillan. doi:10.1057/9780230289925

Samset, K. F., and Volden, G. H. (2014). Front End Governance of Major Public Projects - Lessons with a Norwegian Quality Assurance Scheme. Int. J. Architecture, Eng. Construction 3 (2), 110-119. doi:10.7492/IJAEC.2014.009

Samset, K. F., and Volden, G. H. (2016a). Governance Schemes for Major Public Investment Projects_A Comparative Study of Principles and Practices in Six Countries. Trondheim, Torgarden, Norway: NTNU.

Samset, K. F., and Volden, G. H. (2012). Project Governance: Getting Investments Right. London: Palgrave Macmillan. doi:10.1057/9781137274618

Samset, K., and Volden, G. H. (2016b). Front-end Definition of Projects: Ten Paradoxes and Some Reflections Regarding Project Management and Project Governance. Int. J. Project Management 34 (2), 297-313. doi:10.1016/j.ijproman.2015.01.014

Samset, K. (2009). "Projects, Their Quality at Entry and Challenges in the FrontEnd Phase," in Making Essential Choices with Scant Information: Front-End Decision Making in Major Projects. doi:10.1057/9780230236837

Shenhar, A. J., Dvir, D., Levy, O., and Maltz, A. C. (2001). Project success: A Multidimensional Strategic Concept. Long Range Plann. 34 (6), 699-725. doi:10.1016/S0024-6301(01)00097-8
Shiferaw, A. T., and Klakegg, O. J. (2012). Linking Policies to Projects: The Key to Identifying the Right Public Investment Projects. Project Management J. 43, 14-26. doi:10.1002/pmj.21279

Turner, J. R., and Müller, R. (2003). On the Nature of the Project as a Temporary Organization. Int. J. Project Management 21 (1), 1-8. doi:10.1016/S02637863(02)00020-0

UNESCAP (2009). What Is Good Governance? United Nations Economic and Social Comission for Asia and the Pacific, 1-3. UN Building, Rajdamnern Nok Ave. Bangkok 10200, Thailand. Retrieved from http://www.unescap.org/.

Van Der Vegt, G. S., and Bunderson, J. S. (2005). Learning and Performance in Multidisciplinary Teams: The Importance of Collective Team Identification. Amj 48, 532-547. doi:10.5465/AMJ.2005.17407918

Weaver, P., and Services, P. (2007). Linking PMI's standards to project governance. Paper presented at $P M I^{\circledR}$ Global Congress 2007-Asia Pacific, Hong Kong, People's Republic of China. Newtown Square, PA: Project Management Institute.

Webber, S. S. (2008). Blending Service Provider-Client Project Teams to Achieve Client Trust: Implications for Project Team Trust, Cohesion, and Performance. Project Management J. 39 (2), 72-81. doi:10.1002/ pmj10.1002/pmj.20043

Williams, T., and Samset, K. (2010). Issues in Front-End Decision Making on Projects. Project Management J. 41 (2), 38-49. doi:10.1002/pmj.20160

Woods, N. (2000). The challenge of Good Governance for the IMF and the World Bank Themselves. World Development 28 (5), 823-841. doi:10.1016/S0305750X(99)00156-4

World Bank (1992). Governance and Development. Handbook of Development. Washington, DC. doi:10.1016/B978-0-444-52944-2.00007-0

Conflict of Interest: The authors declare that the research was conducted in the absence of any commercial or financial relationships that could be construed as a potential conflict of interest.

Publisher's Note: All claims expressed in this article are solely those of the authors and do not necessarily represent those of their affiliated organizations, or those of the publisher, the editors and the reviewers. Any product that may be evaluated in this article, or claim that may be made by its manufacturer, is not guaranteed or endorsed by the publisher.

Copyright (c) 2021 Mackhaphonh, Jia and Xu. This is an open-access article distributed under the terms of the Creative Commons Attribution License (CC $B Y)$. The use, distribution or reproduction in other forums is permitted, provided the original author(s) and the copyright owner(s) are credited and that the original publication in this journal is cited, in accordance with accepted academic practice. No use, distribution or reproduction is permitted which does not comply with these terms. 